\title{
Stat5a is mandatory for adult mammary gland development and lactogenesis
}

\author{
Xiuwen Liu, ${ }^{1}$ Gertraud W. Robinson, ${ }^{1}$ Kay-Uwe Wagner, Lisa Garrett, ${ }^{2}$ Anthony Wynshaw-Boris, ${ }^{2}$ \\ and Lothar Hennighausen ${ }^{1,3}$ \\ ${ }^{1}$ Laboratory of Biochemistry and Metabolism, National Institute of Diabetes and Digestive and Kidney Diseases (NIDDK), \\ National Institutes of Health (NIH), Bethesda, Maryland 20892-1812 USA; ${ }^{2}$ Laboratory of Genetic Disease Research, \\ National Center for Human Genome Research, Bethesda, Maryland 20892 USA
}

\begin{abstract}
Prolactin (PRL) induces mammary gland development (defined as mammopoiesis) and lactogenesis. Binding of PRL to its receptor leads to the phosphorylation and activation of STAT (signal transducers and activators of transcription) proteins, which in turn promote the expression of specific genes. The activity pattern of two STAT proteins, Stat5a and Stat5b, in mammary tissue during pregnancy suggests an active role for these transcription factors in epithelial cell differentiation and milk protein gene expression. To investigate the function of Stat5a in mammopoiesis and lactogenesis we disrupted this gene in mice by gene targeting. Stat5a-deficient mice developed normally and were indistinguishable from hemizygous and wild-type littermates in size, weight, and fertility. However, mammary lobuloalveolar outgrowth during pregnancy was curtailed, and females failed to lactate after parturition because of a failure of terminal differentiation. Although Stat5b has a $96 \%$ similarity with Stat5a and a superimposable expression pattern during mammary gland development it failed to counterbalance for the absence of Stat5a. These results document that Stat5a is the principal and an obligate mediator of mammopoietic and lactogenic signaling.
\end{abstract}

[Key Words: Stat5 proteins; epithelial cell differentiation; lactogenesis; mammopoiesis]

Received October 28, 1996; revised version accepted November 22, 1996.

Lobuloalveolar proliferation and differentiation of the mammary gland during pregnancy requires the coordinated action of steroid and peptide hormones (Topper and Freeman 1980). In the cast of characters, prolactin (PRL) appears to be a central player in the promotion of mammopoiesis and lactogenesis (Vonderhaar 1987). PRL was first isolated and identified as a lactogen in 1933 (Riddle et al.), and it can induce lobuloalveolar growth in hypophysectomized virgin rats (Lyons 1958). Induction of terminal differentiation of mammary alveolar cells prior to and at parturition, as indicated by the transcriptional activation of milk protein genes, also requires the presence of prolactin (Topper and Freeman 1980; Pittius et al. 1989; Burdon et al. 1991a).

Binding of PRL to the PRL receptor (PRLR) induces receptor dimerization and activation of Janus kinase 2 (JAK2) (Darnell et al. 1994; Schindler and Darnell 1995). JAK2, in turn, phosphorylates transcription factors that belong to the family of signal transducers and activators of transcription (STAT) (Ihle and Kerr 1995; Schindler and Darnell 1995). Phosphorylation of specific tyrosine residues confers DNA-binding activity to STAT proteins and results in the transcriptional activation of genes containing $\gamma$-interferon activation sites (GAS) (TTCNNNGAA). In vivo experi-

${ }^{3}$ Corresponding author.

E-MAIL mammary@nih.gov; FAX (301) 496-0839. ments in transgenic animals have shown that the GAS sites in the $\beta$-lactoglobulin (BLG) (Burdon et al. 1994) and whey acidic protein (WAP) genes (Li and Rosen 1995) are required for maximal transcription during lactation. PRL has been shown in tissue culture cells to signal through Stat1, Stat3, and Stat5 (DaSilva et al. 1996) and to activate promoters containing the $\beta$-casein gene GAS site (Gouilleux et al. 1994b; Wakao et al. 1994; Liu et al. 1995). In the functional postpartum mammary gland high levels of activated Stat 5 can be found, whereas only small amounts of phosphorylated Stat 1 and Stat 3 are detected (Liu et al. 1996). This led us to hypothesize that the activation of Stat5 is a critical step in the terminal differentiation of mammary secretory epithelial cells (Liu et al. 1996). The two isoforms of Stat5 (a and b) show 96\% similarity (Liu et al. 1995) and form heterodimers upon phosphorylation (Liu et al. 1996). Phosphorylation of both isoforms is very low in mammary tissue of virgins and during early pregnancy but rises sharply after day 14 of pregnancy, supporting the hypothesis that Stat 5 is necessary for alveolar proliferation and differentiation and is a key transcription factor of the WAP gene (Liu et al. 1996). Stat5a and Stat5b are expressed in most if not all tissues, and they can be activated in tissue culture cells by many cytokines and growth modulators, including epidermal growth factor (EGF), growth hormone (GH), erythropoietin (EPO), granulocyte macro- 
phage colony stimulating factor (GM-CSF), different interleukins, and PRL (Ihle and Kerr 1995). This suggests that Stat 5 transcription factors are components of different signaling pathways leading to cell growth and differentiation.

Although Stat5a and Stat5b are homologous, it is unclear whether their functions are purely redundant, or unique in some respects. The only profound difference between Stat5a and Stat5b is within their carboxyl termini (Liu et al. 1995), which encompass a transcriptional activator sequence (Moriggl et al. 1996). To address the role of Stat5a in development, we have generated mice in which the Stat5a gene has been inactivated by homologous recombination. Stat5a-deficient mice are normal in appearance, size, weight, and fertility, suggesting that most cytokine signaling pathways are grossly intact. However, mammary development is impaired in Stat5adeficient mice and females fail to lactate. These results demonstrate an obligate role for Stat5a in mammary growth and differentiation and reveal an unexpected level of specificity when activated under physiological conditions.

\section{Results}

\section{Generation of Stat5a-deficient mice}

Successful targeting of the Stat5a locus was achieved in 4 of the 120 G418-resistant clones (data not shown). Two independently targeted embryonic stem (ES) cell clones were used to produce male chimeras, and germ-line transmission of the disrupted allele was obtained. Heterozygous crosses produced $\mathrm{F}_{2}$ offspring that segregated alleles in a Mendelian 1:2:1 ratio as detected by Southern blot analysis (Fig. 1B). Homozygous Stat5a-deficient mice did not show any overt developmental abnormalities and were indistinguishable from their hemizygous or wild-type littermates on the basis of size, activity, or fertility.

\section{Stat5a-deficient mice fail to lactate}

To evaluate the contribution of Stat5a in mammary development and function, homozygous females were bred. Fertility, length of gravidity, and litter size in Stat5a-deficient mice were comparable to that seen in hemizygous and wild-type littermates. However, the 12 homozygous mothers analyzed up to this point were unable to nurse their young. Despite continued mothering and nurturing by the mothers and constant and vigorous suckling by the pups, no milk was detected in the stomachs of the pups. Upon fostering with hemizygous females, these pups thrived, which suggested that Stat5adeficient females could not produce or eject milk. To test whether the females could produce and secrete milk after an extended period of suckling, we replaced the litter every $12 \mathrm{hr}$ with a set of healthy and strong pups that were accepted by the female and continued to suckle. No signs of successful lactation were obtained, demonstrating that the glands were unable to produce and deliver milk.

Whole-mount analysis of mammary tissue from postpartum Stat5a-deficient mice demonstrated incomplete mammopoiesis (Fig. 2A) compared to hemizygous littermates (Fig. 2B). Ductal development appeared normal,
Figure 1. Targeted disruption of the murine Stat 5 a gene. $(A)$ Schematic representation of 12 $\mathrm{kb}$ of the murine Stat5a gene is shown (top). The open box denotes a $5^{\prime}$ noncoding exon, and the hatched boxes indicate protein coding exons. The double-headed arrow indicates the 6.9-kb BamHI fragment characteristic of the wild-type allele as defined using a labeled DNA fragment derived from the $5^{\prime}$ flanking region of the Stat5a gene (probe). (X) XbaI, (B) BamHI, (E) EcoRI, (K) KpnI and (H) HindIII sites are indicated. The targeting vector shows schematically the position of the PGK-neomycin gene (neo) and the PGK-thymidine kinase gene $(T K)$, oriented as indicated by the arrows. The vector was designed such that the phosphoglycerate kinase-neo cassette replaced the first two protein coding exons of the Stat5a gene together with a noncoding exon and promoter sequences. (B) DNA from wild-type, hemizygous, and homozygous null mice was screened by Southern blot analysis following BamHI digestion and probed with a 32 P-labeled probe derived from the 5 '-flanking region.

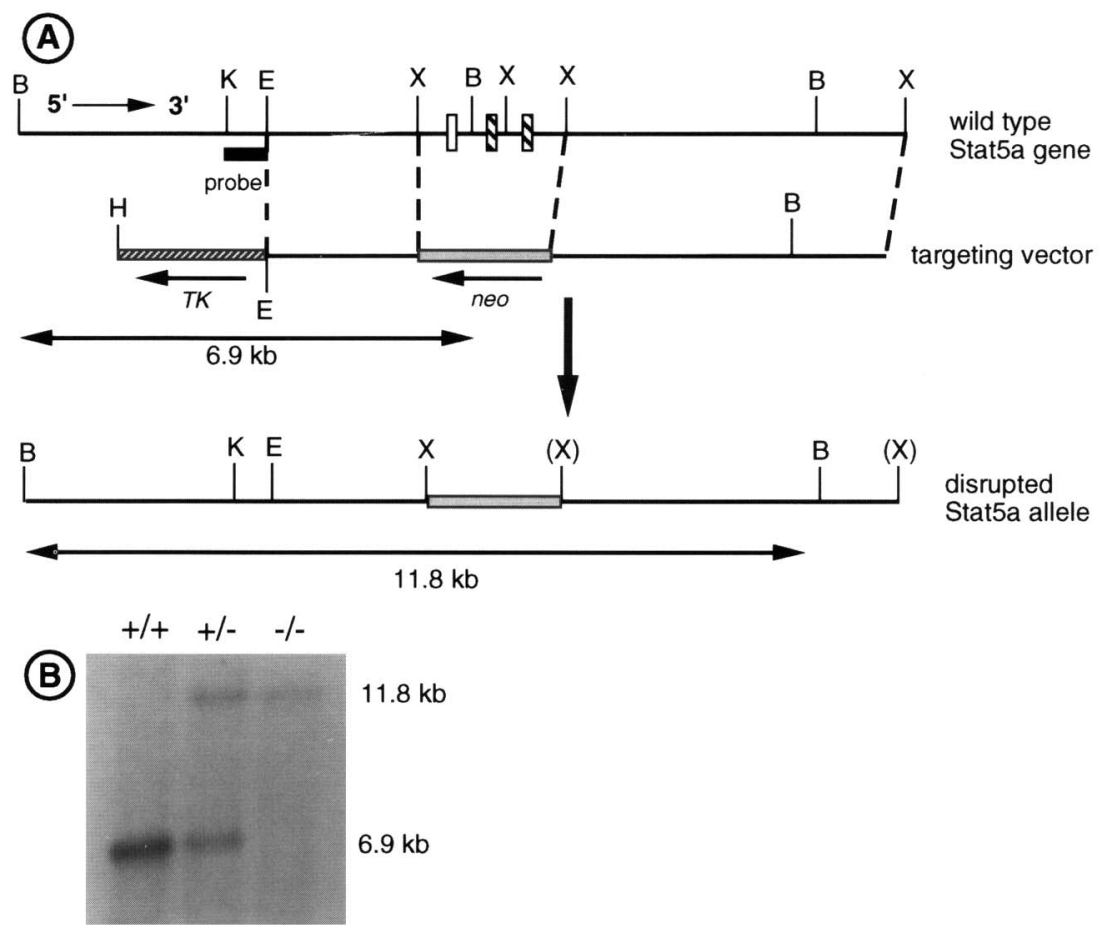



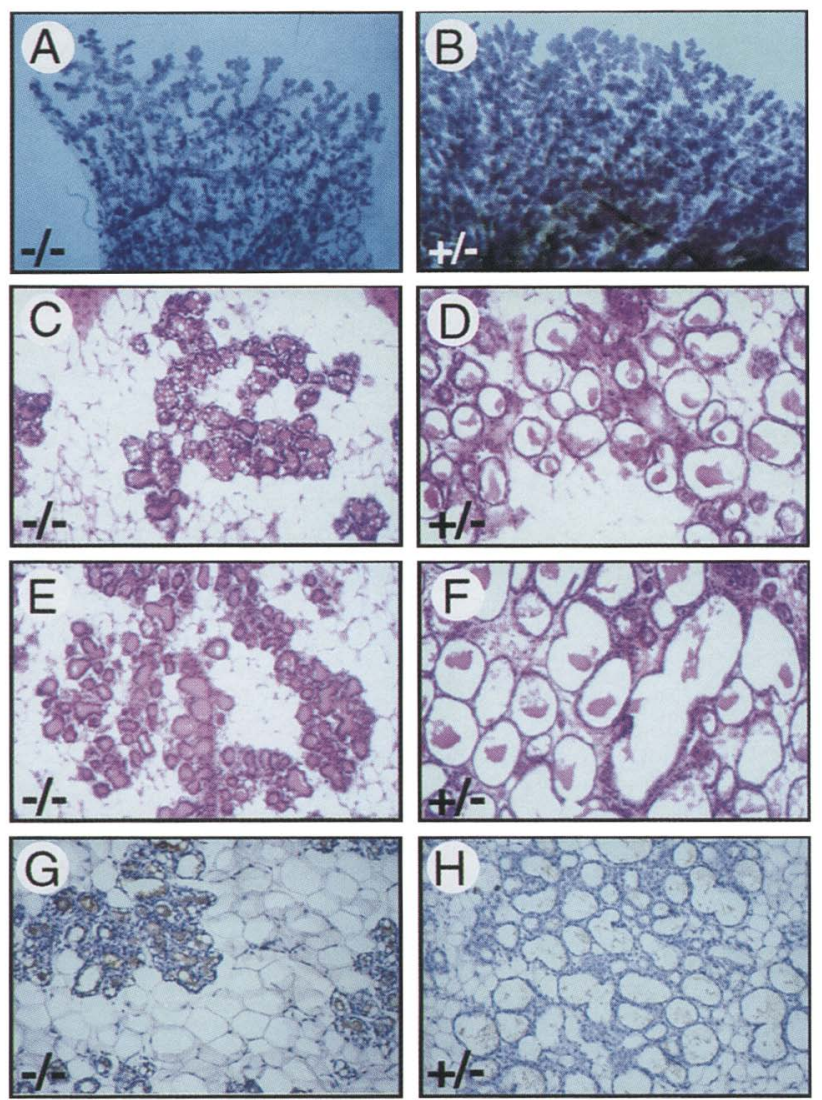

Figure 2. Stat5a-deficient mice display aberrant mammopoiesis. Mammary tissue was biopsied from hemizygous $(B, D, F, H)$ and Stat5a-deficient $(A, C, E, G)$ mothers within $12 \mathrm{hr}$ after parturition $(A-C, G, H)$ or after 3 days of suckling $(E, F)$. $(A, B)$ Wholemount image; $\{C, D\}$ sections of the whole mounts shown in $A$ and $B ;\{E, F\}$ sections of tissue after 3 days of suckling. To maintain suckling in the Stat5a-deficient mice, the mother was provided with a new litter every $12 \mathrm{hr}$. Whole mounts were stained with carmine red; sections were stained with hematoxylin and eosin $(C-F)$ or with anti-WAP antibodies $\{G, H)$.

but lobuloalveolar outgrowth was severely reduced. Thin-section analyses confirmed that secretory tissue from Stat5a-deficient mice was sparse (Fig. 2C). In contrast to alveoli from wild-type or hemizygous mice (Fig. 2D), alveoli from Stat5a-deficient mice were petite and contained small lumina (Fig. 2C). Fat droplets were present within the cytoplasm indicating metabolic activity of the tissue. Continued suckling for 3 days by providing fresh sets of pups twice daily led to some additional lobuloalveolar development (Fig. 2E). However, alveoli and lumina remained small. In contrast, alveoli from hemizygous mice expanded even further (Fig. 2F). In summary, lobuloalveolar units of the Stat5a-deficient mice were underdeveloped and did not exhibit a secretory phenotype, even after maximal stimulation of PRL secretion induced by suckling.

\section{Reduction of Stat $5 b$ activity in Stat5a-deficient mice}

The absence of Stat5a and the presence of Stat5b in ho- mozygous mice was verified using immunoprecipitations and Western blot analyses. Mammary extracts from postpartum hemizygous and homozygous null mice were subjected to immunoprecipitation with antiStat5a antibodies. The immunoprecipitate was separated in an SDS-polyacrylamide gel, transferred to a PVDF membrane and probed consecutively with anti-Stat $5 b$ antibodies to evaluate heterodimer formation, with antiphosphotyrosine antibodies to estimate the amount of active Stat5a, and with anti-Stat5a to visualize the total amount of Stat5a (Fig. 3A). Stat5a was clearly present in mammary tissue from hemizygous mice but completely absent in the null mice. Stat5a-Stat $5 b$ heterodimers were observed in hemizygous, but not in homozygous null mice. As expected, Stat5a in hemizygous mice was tyrosine phosphorylated.

Mammary extracts from the same mice were analyzed for the presence of Stat $5 b$ (Fig. 3B). Stat $5 b$, its heterodimerization with Stat5a, and the phosphorylation were clearly observed in hemizygous mice. In contrast, the level of Stat $5 b$ and its phosphorylation were severely reduced in Stat5a-deficient mice (Fig. 3B). Stat5b levels increased after 3 days of continued suckling, and phosphorylation was apparent (Fig. 3B). To control for loading, mammary extracts were separated in an SDS-polyacrylamide gel, blotted onto a PVDF membrane, and probed directly with anti-Stat $5 b$ antibodies. Again Stat5b was present in much lower levels in the Stat5adeficient mice than in hemizygous littermates (Fig. 3B). Because Stat 3 can also be activated by PRL, we tested whether increased Stat 3 activity could compensate for the absence of Stat5a. However, phosphorylation of Stat3
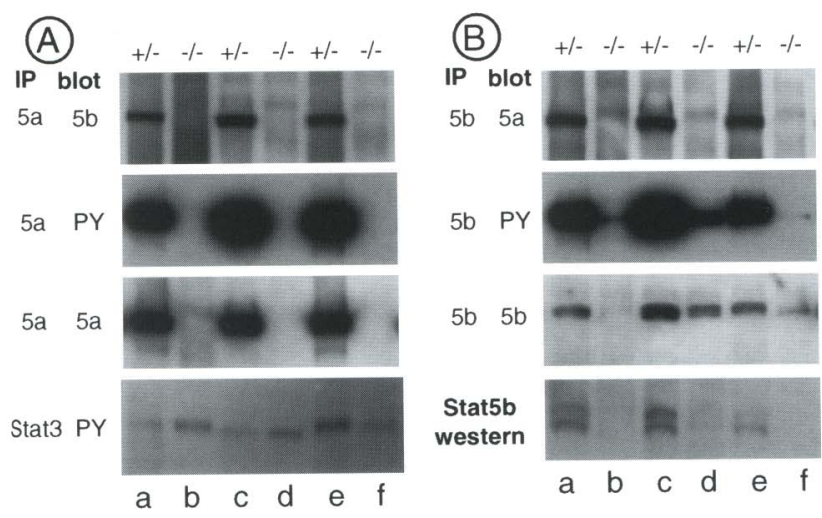

Figure 3. Activation of Stat5a and Stat5b. Mammary tissue from postpartum mice was analyzed for the presence of Stat5aStat $5 b$ heterodimers, tyrosine-phosphorylated Stat5a, tyrosinephosphorylated Stat $5 b$, the presence of Stat5a and Stat $5 b$, the presence of tyrosine-phosphorylated Stat 3 , and Stat $5 \mathrm{~b}$ protein in a Western blot. (Lanes $a, b$ ) Mammary tissue from littermates within $12 \mathrm{hr}$ after parturition; (lanes $e, f$ ) same littermates as shown in lanes $a$ and $b$ but after 3 days of suckling (the histology shown in Fig. 2 is from these mice). To guarantee suckling, the litter of the Stat5a-/-female was switched every $12 \mathrm{hr}$ with that of the Stat $5 \mathrm{a}+/-$ female. (Lanes $c, d$ ) Mammary tissue from a second set of littermates within $12 \mathrm{hr}$ after parturition. 
was not altered significantly in the Stat5a-deficient mice (Fig. 3A; note that the blot with Stat3 was exposed $\sim 500$ times longer than that for Stat5a and Stat5b).

\section{Milk protein genes are expressed in} Stat5a-deficient mice

It has been established in tissue culture cells that mammary gland-specific factors (MGF) (now Stat5a and Stat $5 \mathrm{~b}$ ) activate the $\beta$-casein gene promoter that contains a GAS site (Schmitt-Ney et al. 1991; Gouilleux et al. 1994a; Standke et al. 1994; Liu et al. 1995; Moriggl et al. 1996). Support for an in vivo role of STATs in milk protein gene expression comes from experiments with WAP (Li and Rosen 1995) and BLG (Burdon et al. 1994) transgenes in which the GAS sites had been inactivated. The consequence of a complete absence of Stat5a and reduction of Stat5b on milk protein gene expression was evaluated in Stat5a-deficient mice. RNA was isolated from hemizygous and homozygous null mice, both within $12 \mathrm{hr}$ after parturition, and also after 3 days of suckling, followed by an analysis for the presence of milk protein RNAs (Fig. 4). Within $12 \mathrm{hr}$ after parturition, steady-state levels of $\alpha$-lactalbumin and WDNM1 (another major milk protein) RNA were similar in wildtype, hemizygous, and null mice. However, $\beta$-casein RNA was slightly reduced in null mice, and WAP RNA was reduced to $\sim 10 \%$ (Fig. 4). Upon continued suckling, WAP and $\beta$-casein RNA levels remained constant. WDNM1 and $\alpha$-lactalbumin levels remained constant in null mice but declined in hemizygous mice (Fig. 4). In summary, expression of milk protein genes, with the exception of the WAP gene, is not affected by the complete absence of Stat5a and reduction of Stat5b.

\section{Mammary protein composition in Stat5a-deficient mice}

Total mammary protein from postpartum mice was separated in an $18 \%$ SDS-polyacrylamide gel and either stained with Coomassie blue (Fig. 5A) or blotted onto a PVDF membrane followed by analysis with anti-WAP antibodies (Fig. 5B). The protein pattern in Stat5a-deficient mice was indistinguishable from that in wild-type and hemizygous mice (Fig. 5A). The only clear difference was seen in the amount of WAP (Fig. 5B). In agreement with the Northern blots, WAP levels were greatly reduced in the Stat5a-deficient mice (Fig. 5B).

\section{Secretion of milk proteins}

Translation of milk protein RNAs results in protein precursors containing signal peptides (Hennighausen and Sippel 1982b). As part of the secretion process these signal peptides are cleaved as the nascent protein chain is translocated into the endoplasmic reticulum. Western blot analysis confirmed that WAP was synthesized and processed in mammary tissue of Stat5a-deficient mice, as evidenced by the cleaving of the signal peptide (Fig. 5). To evaluate the ability of alveolar cells to secrete milk proteins, immunocytochemical analyses were performed (Fig. 2G,H). Using anti-WAP antibodies, we observed WAP in the lumina of Stat5a-deficient mice (Fig. 2G), demonstrating that milk proteins were secreted. Because of continued emptying of the glands in hemizygous mice, only little WAP was detected (Fig. 2H).

\section{Discussion}

Stat5a is expressed ubiquitously and can be activated by many cytokines, including interleukins, GH, PRL, EGF, and EPO (Ihle and Kerr 1995; Schindler and Darnell 1995; Liu et al. 1996). This has led to the speculation that its presence is critical for many signaling cascades in vivo. Here we demonstrate that the presence of Stat5a is mandatory for mammopoiesis and lactogenesis.

\section{Lobuloalveolar mammopoiesis}

Development of the mammary gland during the second half of pregnancy is characterized by the growth of secretory units or alveoli. Here we have demonstrated that alveolar development in postpartum Stat5a-deficient mice is curtailed and has the appearance of a gland at mid-pregnancy. The developmental abnormalities in

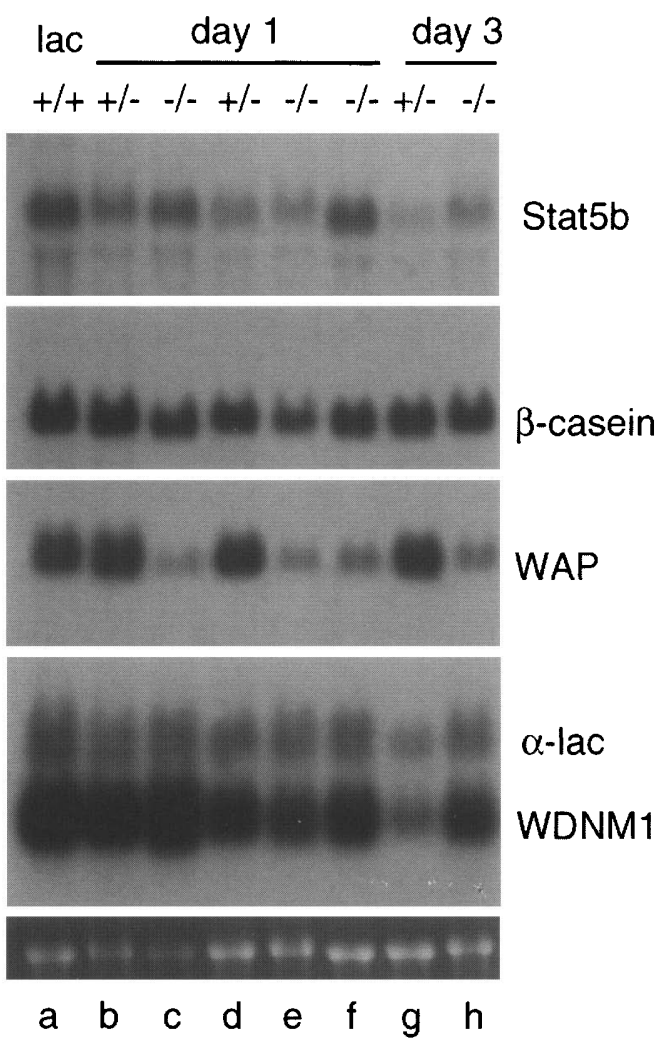

Figure 4. Expression of milk protein genes. Mammary tissue from wild-type, hemizygous, and homozygous mice was biopsied within $12 \mathrm{hr}$ after parturition (lanes $a-f$ ) or after 3 days of suckling $($ lanes $g, h)$ and probed for the presence of RNA encoding Stat $5 b, \beta$-casein, WAP, $\alpha$-lactalbumin, and WDNM1. 


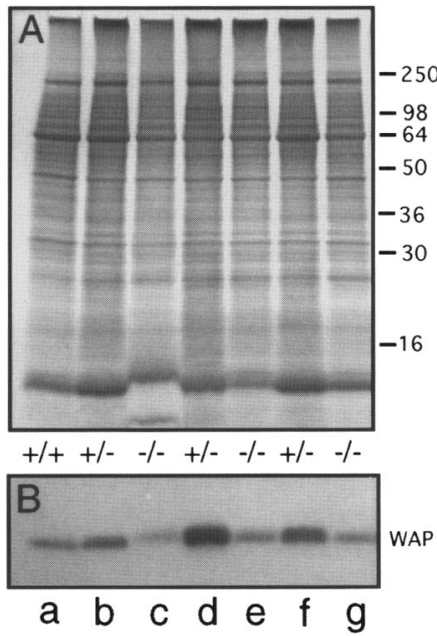

Figure 5. Protein composition in mammary tissue of Stat5adeficient mice. Protein extracts from mammary tissue biopsies of wild-type, hemizygous, and homozygous mice isolated within $12 \mathrm{hr}$ after parturition (lanes $a-e$ ) or after 3 days of suckling (lanes $f, g$ ) were analyzed by Coomassie blue staining $(A)$ and probed for the presence of WAP using anti-WAP antibodies $(B)$. The molecular masses (in $\mathrm{kD}$ ) of a standard run in the same gel are indicated at right. The data shown in Figs. 2-5 were from the same mice.

Stat5a-deficient mice are consistent with a role of Stat5a in mammopoiesis predicted by previous studies that showed a sharp increase of its activity at mid-pregnancy (Liu et al. 1996). Although GH, PRL, and EGF can signal through Stat5a and Stat5b and induce alveolar growth in specific experimental settings, a large body of in vivo and in vitro studies implicates PRL [and perhaps placental lactogen $(\mathrm{PL})]$ as a prime candidate for the control of mammary alveolar development and differentiation in late pregnancy (Vonderhaar 1987). Recent studies of mice, in which one allele of the PRLR has been inactivated, support the hypothesis that the PRL pathway is critical for alveolar development (Ormandy et al., this issue). However, other growth factors may perform auxiliary functions. Ectopic expression of $\mathrm{GH}$ in transgenic mice induces precocious mammary development and epithelial cell differentiation (Bchini et al. 1991), but a clear in vivo role of GH in mammary morphogenesis has not been established yet. The GH signaling pathway in Stat5a-deficient mice appears intact, as indicated by the normal developmental weight gain of male and females (data not shown). This is in stark contrast to Stat5bdeficient mice where reduced growth rates in males has been observed (H. Davey, pers. comm.). If GH contributes to mammary development, its effects may be conveyed through Stat5b. EGF can also enhance mammary development in organ cultures (Vonderhaar 1987). Because EGFR-deficient mice die within the first 3 weeks of life (Miettinen et al. 1995), a thorough analysis of their breast development has been difficult to perform.

\section{Activation of milk protein genes}

WAP and $\beta$-casein RNAs were detected in postpartum mammary tissue from Stat5a-deficient mice, demonstrating that other signals must counterbalance the lack of Stat5a. Although Stat 1 and Stat 3 can be activated by PRL in tissue culture cells (DaSilva et al. 1996) their activity in lactating mammary tissue is at least 500 -fold lower than that of Stat5a and Stat5b (Liu et al. 1996). Stat5b activity in Stat5a-deficient mice is greatly reduced. If Statl, Stat3, or Stat5b compensate for Stat5a activity, it is clearly accomplished by a low level of active protein. Based on the expression of milk protein genes in Stat5a-deficient mice it is necessary to reevaluate the role of Stat5a and Stat5b, in particular for the $\beta$-casein gene. We propose that maximum $\beta$-casein gene expression can be accomplished with very little Stat $5 \mathrm{~b}$ in the absence of Stat5a. In contrast, high expression of the WAP gene requires high levels of Stat5a. The activity pattern of Stat 5 during pregnancy does not correlate with $\beta$-casein gene expression but coincides with WAP gene expression (Liu et al. 1996). Differential regulation of the WAP and $\beta$-casein genes by prolactin has been reported earlier (Hobbs et al. 1982; Pittius et al. 1988; Burdon et al. 1991a), and one molecular basis has now been established as a differential requirement for Stat5a. The reduction of WAP gene expression in the absence of Stat $5 \mathrm{a}$ is comparable to that seen in WAP transgenes with a mutated Stat 5 binding site (Li and Rosen 1995). The residual WAP gene activity may be induced by other transcription factors such as NF1 and GR (Li and Rosen 1995) and Ets proteins (McKnight et al. 1995). Stat5b may be dispensible for WAP gene expression in vivo as Stat5bdeficient mice are able to lactate $(\mathrm{H}$. Davey, pers. comm.).

\section{Lactogenesis}

Full mammary growth is not attained until the alveoli enlarge to their functional secretory state. Lactogenesis may thus be considered the final stage of mammopoiesis. An early sign of a shift to a secretory parenchymal phase of lactogenesis during mid-pregnancy is the formation of fat droplets in the alveolar epithelium, followed by further alveolar cell proliferation and considerable enlargement of the alveolar lumina. Although we have a clear phenotypic understanding of the lobuloalveolar defects in the absence of Stat5a, the cause of lactation failure is still elusive. The mechanisms by which alveolar lumina expand are not fully understood. One possibility for the failure of lumina to expand in Stat5a-deficient mice could be the lack of water flow into the lumen, which in turn is believed to be dependent on lactose. However, the phenotype of the Stat5a-deficient mice differs from that seen in the absence of $\alpha$-lactalbumin (Stinnakre et al. 1994). These females do not produce lactose and therefore have thickened milk, but alveolar size and luminal expansion is apparently normal. Although the accumulation of milk proteins and fat droplets in alveolar cells of Stat5a-deficient mice are clear indicators of a successful completion of early steps in lactogenesis, little or no expansion of the lumina was detected, even after extended periods of suckling. Even though continued suck- 
ling did not result in milk production and release, the expression of milk protein genes and the synthesis of milk proteins was maintained and the gland did not involute. This is in sharp contrast to other instances in which failure of complete mammopoiesis and lactogenesis has been observed. Similarly to the Stat5a-deficient mice, small lumina coupled with lactation failure has been observed in mammary tissue in which $\mathrm{pRb}$ and $\mathrm{p} 53$ was inactivated through the expression of the SV40 Tantigen (Li et al. 1996). However, deregulation of the cell cycle resulted in the induction of apoptosis in the epithelial cells and the expression of milk protein genes was sharply reduced within $24 \mathrm{hr}$ after parturition ( $\mathrm{Li}$ et al. 1996).

The lack of Stat5a clearly leads to the deregulation of one or several genes critical for normal mammopoiesis. Although the genes in question are still elusive, the WAP gene may be a promising candidate. WAP is a mammary protein belonging to a family of protease inhibitors containing a four-disulfide core, but its role in normal mammary function is unknown (Hennighausen and Sippel 1982a). Its expression during pregnancy is tightly regulated, and precocious activation in transgenic mice also results in a developmental arrest at mid-pregnancy, small lumina, and a milchlos phenotype (Burdon et al. 1991b). Interestingly, the overall protein pattern from Stat5a-deficient mammary tissue indicates that WAP is the only milk protein with reduced expression.

\section{Genes and mammary development}

Disruption of mammopoiesis and lactogenesis has been observed upon the deletion of several genes from the mouse genome. Lobuloalveolar outgrowth is severely inhibited in the absence of cyclin D1 (Sicinski et al. 1995), the progesterone (Lydon et al. 1995), and PRL (Ormandy et al., this issue) receptors, the activin/inhibin $\beta B$ gene (Vassalli et al. 1994), and, as shown in this report, Stat5a. Although each of these gene products is part of signaling pathways leading to alveolar cell proliferation and differentiation, we do not know at this point whether they function in the same or distinct pathways.

It is intriguing to speculate why widespread and general signaling cascades involving transcription factors, cyclins, hormones, and growth factors are so critical for mammopoiesis and lactogenesis, whereas their requirements for the development of other tissues appears to be far less stringent. Becasue the mammary gland arrived late, if not last, in the phylogenetic scale of organ evolution, it may well be possible that redundant signaling pathways have not been developed in the mammary gland. There is experimental evidence to support such a view. Many cytokines, including EGF, GH, EPO, GMCSF, and PRL, can activate Stat5a and Stat5b as well as Stat 1 and Stat 3 (for recent references, see Liu et al. 1996). Although PRL activates Stat5 and Stat 3 to a similar extent in some lymphoid and breast cancer cells (DaSilva et al. 1996), Stat 1 and Stat3 activities are barely detectable in the lactating mammary gland and do not correlate with prolactin levels (Liu et al. 1996). Thus, PRL- mediated pathways activating Stat 1 or Stat 3 were perhaps never established in the mammary gland and therefore cannot compensate for the loss of Stat5a.

The superimposable expression pattern of Stat5a and Stat5b during pregnancy and lactation in conjunction with the $96 \%$ sequence similarity between the two isoforms was a harbinger that Stat $5 \mathrm{~b}$ might be able to compensate for the loss of Stat5a. Unexpectedly, Stat5b protein levels, and even more pronounced the extent of phosphorylation but not the RNA levels, were greatly reduced in Stat5a-deficient mammary tissue. This demonstrates that efficient phosphorylation of Stat $5 b$ requires the presence of Stat5a and suggests that a docking of both molecules to the receptor complex is critical for maximum activation. The importance of Stat5a-Stat5b heterodimerization for mammary cell differentiation had been postulated previously (Liu et al. 1996). Reduced amounts of phosphorylated Stat5b were detected in Stat5a-deficient mammary tissue, and we did not observe a functional compensation of Stat5a deficiency, suggesting that the two molecules exhibit unique biochemical activities. This is supported by the phenotype of Stat5b-deficient mice, which differs dramatically from the Stat5a mice and includes reduced growth and fertility (H. Davey, pers. comm.). Stat5a and Stat5b exhibit similar if not identical transcription properties in tissue culture cells, and their only difference resides in the 15 carboxy-terminal amino acids, a region mediating transcriptional activation (Moriggl et al. 1996). However, the physiological properties of these homologous proteins are different when investigated in the living organism.

\section{Materials and methods}

Cloning of mouse Stat5a gene

A $\lambda$ FIX II library (Stratagene, La Jolla, CA, cat. no. 946309) containing Sau3AI partially digested liver DNA isolated from 4to 8-week-old female mice of the strain 129SVJ was probed with a PCR fragment amplified from Stat5a cDNA encoding amino acids 66-166 (Liu et al. 1995). Two overlapping clones encoding Stat 5 a were isolated and restriction mapped, and the exon regions were identified by hybridizing to various oligonucleotides derived from different regions of Stat5a cDNA. The 5' part of the gene used for making the knockout construct was sequenced.

Construction of targeting plasmid, transfection of ES cells, and generation of Stat5a-disrupted mice

A targeting construct (Fig. 1A) containing a 2.2-kb EcoRI-XbaI fragment from the $5^{\prime}$-upstream region and a $5.0-\mathrm{kb} X b a \mathrm{I}-\mathrm{XbaI}$ fragment derived from the internal region of the Stat 5 a gene was interrupted by a phosphoglycerate kinase-neo (PGK-neo) gene in an opposite orientation relative to the Stat 5 a transcription, using pPNT (Tybulewicz et al. 1991). The plasmid was linearized and transfected into TC1 ES cells as described previously (Deng et al. 1996). After positive/negative selection with G418 and FIAU, we picked 120 colonies and screened them for correct targeting by Southern blot analysis using an external probe (Fig. 1A), and four clones were positively identified. Two of the four clones were injected into $\mathrm{C} 57 \mathrm{BL} / 6 \mathrm{~J}$ blastocysts. One clone produced high-level chimeras that gave germ-line transmission 
when bred to NIH Black Swiss or the 129SvEv inbred strain. Heterozygous mice were intercrossed to generate wild-type, heterozygous, and homozygous mutant mice. All animal experiments were carried out according to the NIH Guidelines.

\section{Histology and immunocytochemistry}

Mammary tissues were biopsied on the first day postpartum. Pups from the heterozygous and null mothers were circulated between mothers twice daily over a period of 3 days to maintain the suckling stimulus. After 3 days the females were sacrificed, and the remaining mammary tissue was taken. For wholemount examination the tissues were fixed in Carnoy's solution for $2 \mathrm{hr}$ and stained with carmine alum overnight as described previously (Kordon et al. 1995). The whole mounts were embedded and sectioned using standard methods. Mammary sections were stained with hematoxylin and eosin and used for histological analysis. Antibody staining of mammary sections with WAP antibodies has been descibed previously (Robinson et al. 1995).

\section{Protein and RNA analyses}

Protein extraction, Western blotting, and immunoprecipitation were performed as described previously (Liu et al. 1996). Antibodies for Stat $5 a$, Stat $5 b$, and phosphotyrosine have been described (Liu et al. 1996). Total cellular RNA was isolated, and Northern blot analyses were done as described (Robinson et al. 1995). The probes for Stat5b (Liu et al. 1995), WAP, $\beta$-casein, WDNM1, and $\alpha$-lactalbumin have also been described previously (Robinson et al. 1995). Quantitation of WAP and $\beta$-casein mRNA levels were performed using a Fuji PhosphorImager.

\section{Acknowledgements}

We thank Theresa Hernandez and David Bernard for animal husbandry and technical support, and Kathrin Heermeier and Priscilla Furth for stimulating discussions.

The publication costs of this article were defrayed in part by payment of page charges. This article must therefore be hereby marked "advertisement" in accordance with 18 USC section 1734 solely to indicate this fact.

\section{References}

Bchini, O., A.-C. Andres, B. Schubaur, M. Methali, M. LeMeur, R. Lathe, and P. Gerlinger. 1991. Precocious mammary gland development and milk protein synthesis in transgenic mice ubiquitously expressing human growth hormone. Endocrinology 128: 539-546.

Burdon, T., L. Sankaran, R.J. Wall, M. Spencer, and L. Hennighausen. 1991a. Expression of a whey acidic protein transgene during mammary development: Evidence for different mechanisms of regulation during pregnancy and lactation. $I$. Biol. Chem. 266: 6909-6914.

Burdon, T., R.J. Wall, A. Shamay, G. Smith, and L. Hennighausen. 1991b. Over-expression of an endogenous milk protein gene in transgenic mice is associated with impaired mammary alveolar development and a milchlos phenotype. Mech. Dev. 36: 67-74.

Burdon, T.G., K.A. Maitland, A.J. Clark, R. Wallace, and C.J. Watson. 1994. Regulation of the sheep beta-lactoglobulin gene by lactogenic hormones is mediated by a transcription factor that binds an Interferon-gamma activation site-related element. Mol. Endocrinol. 8: 1528-1536.
Darnell, J.E. Jr., I.M. Kerr, and G.R. Stark. 1994. Jak-STAT pathways and transcriptional activation in response to IFNs and other extracellular signaling proteins. Science 264: 1415-1421.

DaSilva, L., H. Rui, R.A. Erwin, O.M.Z. Howard, R.A. Kirken, M.G. Malabarba, R.H. Hackett, A.C. Larner, and W.L. Farrar. 1996. Prolactin recruits Stat1, Stat 3 and Stat 5 independent of conserved receptor tyrosines TYR402, TYR479, TYR515 and TYR580. Mol. Cell. Endocrinol. 117: 131-140.

Deng, C., A. Wynshaw-Boris, A. Kuo, F. Zhou, and P. Leder. 1996. Fibroblast growth factor receptor-3 is a negative regulator of bone growth and development. Cell 84: 911-921.

Gouilleux, F., C. Pallard, I. Dusanter-Fourt, H. Wakao, L.-A., Haldosen, G. Norstedt, D. Levy, and B. Groner. 1994a. Prolactin, growth hormone, erythropeoietin and granulocytemacrophage colony factor induce MGF-Stat5 DNA binding activity. EMBO T. 14: 2005-2013.

Gouilleux, F., H. Wakao, M. Mundt, and B. Groner. 1994b. Prolactin induces phosphorylation of Tyr694 of Stat5 (MGF), a prerequisite for DNA binding and induction of transcription. EMBO \%. 13: 4361-4369.

Hennighausen, L.G. and A.E. Sippel. 1982a. The mouse whey acidic protein is a novel member of the family of "fourdisulfide core" proteins. Nucleic Acids Res. 10: 2677-2684.

- 1982b. Characterization and cloning of the mRNAs specific for the lactating mouse mammary gland. Eur. J. Biochem. 257: 131-141.

Hobbs, A.A., D.A. Richards, D.J. Kessler, and J.M. Rosen. 1982. Complex hormonal regulation of rat casein gene expression. I. Biol. Chem. 125: 3598-3605.

Ihle, J.N. and I.M. Kerr. 1995. Jaks and Stats in signaling by the cytokine receptor superfamily. Trends Genet. 11: 69-74.

Kordon, E.C., R.A. McKnight, C. Jhappan, L. Hennighausen, G. Merlino, and G.H. Smith. 1995. Ectopic TGF beta 1 expression in the secretory mammary epithelium induces early senescence of the epithelial stem cell population. Dev. Biol. 168: 47-61.

Li, M., J. Hu, K. Heermeier, L. Hennighausen, and P.A. Furth. 1996. Expression of a viral oncoprotein during mammary gland development alters cell fate and function: Induction of p53-independent apoptosis is followed by impaired milk protein production in surviving cells. Cell Growth Differ. 7: 311.

Li, S. and J.M. Rosen. 1995. Nuclear factor I and mammary gland factor (STAT5) play a critical role in regulating rat whey acidic protein gene expression in transgenic mice. Mol. Cell. Biol. 15: 2063-2070.

Liu, X., G.W. Robinson, F. Gouilleux, B. Groner, and L. Hennighausen. 1995. Cloning and expression of Stat5 and an additional homologue (Stat5b) involved in prolactin signal transduction in mouse mammary tissue. Proc. Natl. Acad. Sci. 92: 8831-8835.

Liu, X., G.W. Robinson, and L. Hennighausen. 1996. Activation of Stat 5 and Stat 5 b by tyrosine phosphorylation is tightly linked to mammary gland differentiation. Mol. Endocrinol. (in press).

Lydon, J.P., F.J. DeMayo, C.R. Funk, S.K. Mani, A.R. Hughes, C.A. Montgomery, G. Shyamala, O.M. Conneely, and B.W. O'Malley. 1995. Mice lacking progesterone receptor exhibit pleiotropic reproductive abnormalities. Genes \& Dev. 9: 2266-2278.

Lyons, W.R. 1958. Hormonal synergism in mammary growth. Proc. Royal Soc. London 149: 303-325.

McKnight, R.A., M. Spencer, J. Dittmer, J. Brady, R.J. Wall, and L. Hennighausen. 1995. An Ets site in the whey acidic protein gene promoter mediates transcriptional activation in 
Liu et al.

the mammary gland of pregnant mice but is dispensable during lactation. Mol. Endocrinol. 9: 717-724.

Miettinen, P.J., J.E. Berger, J. Meneses, Y. Phung, R.A. Pedersen, Z. Werb, and R. Derynck. 1995. Epithelial immaturity and multiorgan failure in mice lacking epidermal growth factor receptor. Nature 376: 337-341.

Moriggl, R., V. Gouilleux-Gruart, R. Jaehne, S. Berchtold, C. Gartmann, X. Liu, L. Hennighausen, A. Sotiropoulos, B. Groner, and F. Gouilleux. 1996. Deleteion of the carboxyterminal transactivation domain of MGF-Stat5 results in sudtained DNA binding and a dominant negative phenotype. Mol. Cell. Biol. 16: 5691-5700.

Ormandy, C.J., A. Camus, J. Barra, D. Damotte, B. Lucas, H. Buteau, M. Edery, N. Brousse, C. Babinet, N. Binart, and P.A. Kelly. 1997. Null mutation of the prolactin receptor gene produces multiple reproductive defects in the mouse. Genes \& Dev. (this issue).

Pittius, C.W., S. Sankaran, Y. Topper, and L. Hennighausen. 1988. Comparison of the regulation of the whey acidic protein gene to a hybrid gene containing the whey acidic protein gene promoter in transgenic mice. Mol. Endocrinol. 2: 10271032.

Riddle, O., R.W. Bates, and S.W. Dykshorn. 1933. The preparation, identification and assay of prolactin-a hormone of the anterior pituitary. Am. J. Physiol. 105: 191-216.

Robinson, G.W., R.A. McKnight, G.H. Smith, and L. Hennighausen. 1995. Mammary epithelial cells undergo secretory differentiation in cycling virgins but require pregnancy for the establishment of terminal differentiation. Development 121: 2079-2090.

Schindler, C. and J.E. Darnell. 1995. Transcriptional responses to polypeptide ligands: The Jak-STATpathway. Annu. Rev. Biochem. 64: 621-651.

Schmitt-Ney, M., W. Doppler, R.K. Ball, and B. Groner. 1991. Beta-casein gene promoter activity is regulated by the hormone mediated relief of transcriptional repression and a mammary gland specific factor. Mol. Cell. Biol. 11:37453755.

Sicinski, P., J.L. Donaher, S.B. Parker, T. Li, A. Fazeli, H. Gardner, S.Z. Haslam, R.T. Bronson, S.J. Elledge, and R.A. Weinberg. 1995. CyclinD1 provides a link between development and oncogenesis in the retina and breast. Cell 82: 621-630.

Standke, G.J., V.S. Meier, and B. Groner. 1994. Mammary gland factor activated by prolactin on mammary epithelial cells and acute-phase response factor activated by interleukin- 6 in liver cells share DNA binding and transactivation potential. Mol. Endocrinol. 8: 469-477.

Stinnakre, M.G., J.L. Vilotte, S. Soulier, and J.C. Mercier. 1994. Creation and phenotypic analysis of $\alpha$-lactalbumin deficient mice. Proc. Natl. Acad. Sci. 91: 6544-6548.

Topper, Y.J. and C.S. Freeman. 1980. Multiple hormone interactions in the developmental biology of the mammary gland. Physiol. Rev. 60: 1049-1056.

Tybulewicz, V.L., C.E. Crawford, P.K. Jackson, R.T. Bronson, and R.C. Mulligan. 1991. Neonatal lethality and lymphopenia in mice with a homozygous disnuption of the c-abl protooncogene. Cell 65: 1153-1163.

Vassalli, A., M.M. Matzuk, H.A.R. Gardner, K.-F. Lee, and R. Jaenisch. 1994. Activin/inhibin $\beta$ B subunit gene disruption leads to defects in eyelid development and female reproduction. Genes \& Dev. 8: 414-427.

Vonderhaar, B.K. 1987. Prolactin: Transport, function, and receptors in mammary gland development and differentiation. In The mammary gland. (ed. M.C. Neville and C.W. Daniel), pp. 383-438, Plenum Press, New York.

Wakao, H., F. Gouilleux, and B. Groner. 1994. Mammary gland factor (MGF) is a novel member of the cytokine regulated transcription factor gene family and confers the prolactin response. $E M B O$ I. 13: 2182-2191. 


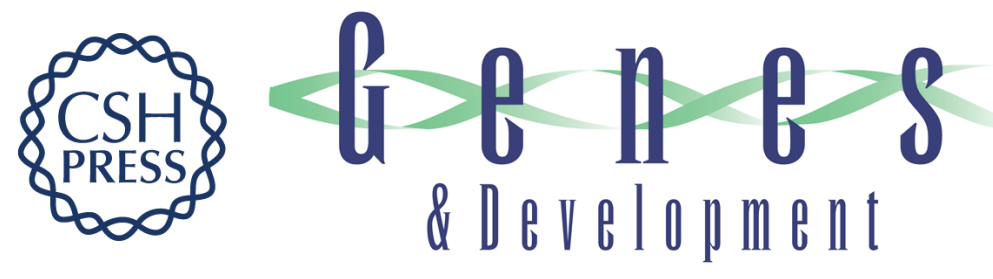

\section{Stat5a is mandatory for adult mammary gland development and lactogenesis.}

X Liu, G W Robinson, K U Wagner, et al.

Genes Dev. 1997, 11:

Access the most recent version at doi:10.1101/gad.11.2.179

References This article cites 34 articles, 10 of which can be accessed free at: http://genesdev.cshlp.org/content/11/2/179.full.html\#ref-list-1

License

Email Alerting Receive free email alerts when new articles cite this article - sign up in the box at the top Service right corner of the article or click here.

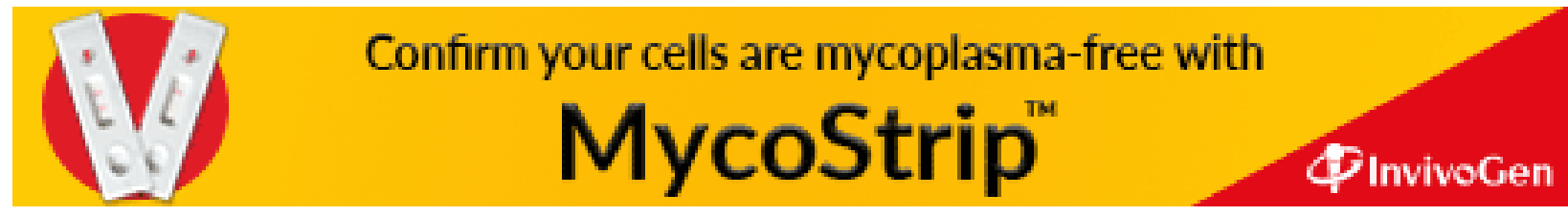

